\title{
Recycling waste from natural stone processing plants to stabilise clayey soil
}

\author{
Osman Sivrikaya $\cdot$ Koray R. Kıyıldı • \\ Zeki Karaca
}

Received: 26 January 2013/ Accepted: 26 September 2013/Published online: 4 October 2013

(C) The Author(s) 2013. This article is published with open access at Springerlink.com

\begin{abstract}
For the countries with a developed stone industry the waste generated in the natural stone processing plants pose environmental and economic problems. The utilisation of stone waste in various areas is still under research. In addition, there are only a limited number of studies concerning the use of stone waste obtained from processing plants in the stabilisation of clayey soil. Furthermore, none of the studies in the literature investigated the effect of the characteristics of the stone on the stabilisation of the soil. This is the first study that compares the efficiency of the waste calcitic marble, dolomitic marble and granite powder as additives for the stabilisation of clayey soil. Artificial soil samples were prepared in the laboratory using bentonite and kaolinite. Natural stone waste powder was added to the soil samples at different percentages, and the index and compaction parameters of the stabilised soil were analysed. The results showed that the types of waste powder used in this study, like lime, could be used as stabilisers. As the percentage of additives increased, the plasticity index of the clayey soil decreased and the physical properties of the soil changed from clay to silt. In terms of compaction parameters, the use of all types of natural waste powder in the study resulted in a decrease in the optimum water content and an increase in the maximum dry unit weight. The lowest optimum water content and the highest maximum dry unit weight were obtained from the dolomitic marble powder.
\end{abstract}

O. Sivrikaya $(\varangle) \cdot$ K. R. Kıyıldı

Department of Civil Engineering, Nigde University,

51240 Nigde, Turkey

e-mail: osivrikaya@nigde.edu.tr; sivrikayaosman@hotmail.com

Z. Karaca

Department of Mining Engineering, Nigde University,

51240 Nigde, Turkey
Keywords Natural stone plant wastes .

Stabilisation · Clay $\cdot$ Index properties $\cdot$ Compaction

\section{Introduction}

As in all industrial activities, waste production is also inevitable in natural stone quarries and plants, and the negative environmental impact of this waste poses a problem. Turkey is among the first three economies in the world in terms of growth rate and the construction industry is a very important part of the economy. On the other hand, companies have a social responsibility to protect the environment and ensure the sustainable use of natural resources (Fig. 1). Thus, for a sustainable economy, industrialisation and the use of natural resources should be accompanied by environmental protection (Mymrin 1997). The most important stage in achieving this balance is that waste produced in one area is reused either within the same area, in another industry or for another purpose such as soil stabilisation, concrete, aggregate source, new and binding materials (Gürer et al. 2004; Karaca 2009; Zega et al. 2010; Güllü and Girisken 2012).

The continuing increase in world population results in a higher demand for new construction such as housing, public buildings and roads, thus the need for construction materials increases. Materials obtained by conventional methods are not sufficient to satisfy this demand. To ensure the sustainability of geotechnical and building construction, it is essential to utilise production waste as well as to create new sources of materials. Every year a large part of recyclable materials is disposed of in landfills or arbitrarily discharged to the environment. Therefore, researchers are interested in finding ways of eliminating the negative impacts of waste and obtaining economic benefits from the 


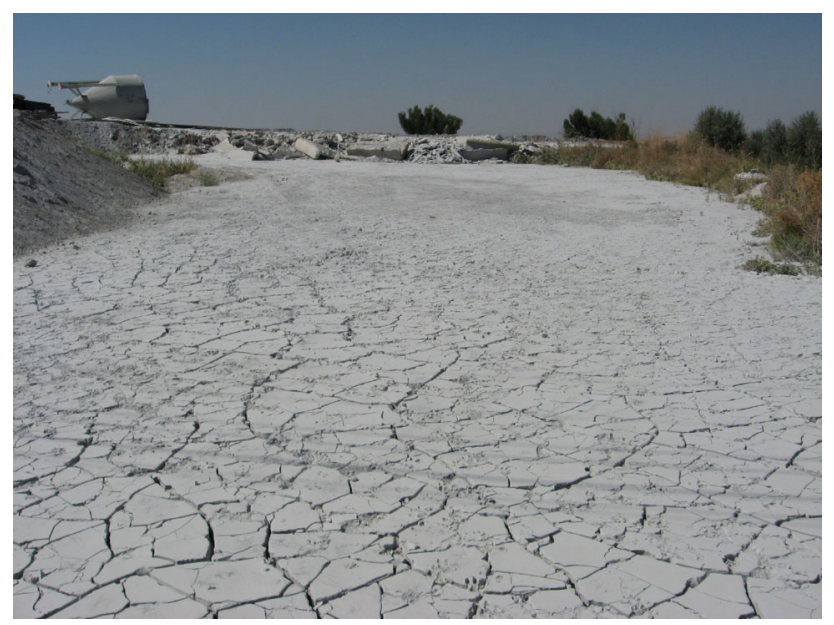

Fig. 1 View of natural stone plant waste

recycled material (Gürer et al. 2004; Karaca 2009; Edil 2011; Altuncu and Kasapseçkin 2011).

There were some difficulties experienced in Turkey in terms of waste material utilisation, which resulted in a significant economic loss. While the recycling rate of waste is approximately $80 \%$ in Western Europe and the USA, it is only about $20 \%$ in Turkey. Every year, the reuse of aggregates in asphalt pavement is over 93 million tons. Considering that the $90 \%$ of the asphalt pavement materials consist of aggregates, it is obvious that the reuse of this material significantly contributes to the economy and reduces damage to the environment. In addition, almost $50 \%$ of the marble blocks obtained from marble quarries become waste materials (Gürer et al. 2004; Karaca 2009).

The use of industrial waste as additives in the stabilisation of soil has been a subject of research in recent years. In addition to lime, cement and bitumen, industrial waste materials such as fly ash, silica fume and blast furnace stag have been used as additives in soil stabilisation for the last two decades. Natural stone waste such as waste marble and granite consisting of particles smaller than 100 microns (Gürer et al. 2004; Sarısoy 2010) can now be used as soil stabilisers, concrete aggregates and fill materials for road building and the construction sector is the largest and most important sector in which natural stone waste can be used (Karaca et al. 2012). Investigating the use of waste obtained from natural stone plants in soil stabilisation and the impacts of different types of waste on soil will help determine the most economic and suitable waste to be used for each soil type.

Soil stabilisation is a procedure in which natural or manufactured additives are used to improve the properties of soils. One of the stabilisation methods of clayey soils is the chemical stabilisation. Chemical additives such as lime, cement, fly ash, and other chemical compounds have been utilised in clayey soil stabilisation for many years with various degrees of success (Al-Rawas et al. 2002). All the chemical additives used to stabilise expansive soils have cementitious property. Cementitious materials stabilise clayey soils and modify their properties through cation exchange, flocculation and agglomeration, and pozzolanic reactions. In addition, cement provides hydration products, which increase the strength of the base materials as well as enhance the performance of the treatment. Pozzolanic reaction is a secondary process of soil stabilisation. One prerequisite for the formation of additional cementing materials is the solution of silica and alumina from clay components (Wang 2002).

Knowing which natural stone waste to use for the stabilisation of clayey soil and in what amount will not only reduce the widely known environmental impacts of this waste but also fulfil a social responsibility by ensuring the controlled use of non-renewable resources and offer a way for the construction industry to meet its increasing demands for material. When the soil, on which buildings, highways, airports, dams and tunnels are to be built, is soft, loose or expansive and thus do not have the desired properties for construction, the best solution is to stabilise or improve the soil. Therefore, the search for materials to be used in soil stabilisation is one of the leading areas of interest for researchers to eliminate the problems related to the swelling of expansive clayey soil, thus improving the soil bearing capacity and consolidation in soft clayey soil, and the seepage properties of the materials used in the construction of dams, cut-off walls and blankets.

In this regard, it is necessary to investigate the use of waste produced in natural stone processing plants in soil stabilisation both in terms of the utilisation of these waste and the elimination of their negative environmental impacts. Therefore, this study compares the efficiency of the waste calcitic marble, dolomitic marble and granite as additives in the stabilisation of bentonite and kaolinite clay soil with different levels of plasticity. The results of this study show that selecting the type of natural stone waste that is most suitable for the properties of the soil to be stabilised and determining the effect of these waste on the index and compaction parameters of clayey soil will contribute to the better utilisation of waste generated in the natural stone industry.

\section{Previous studies}

There are various studies on the use of natural stone waste in granule and powder form: as raw materials in the production of joint sealants, as additives in brick and concrete production and soil stabilisation, and as aggregates in asphalt pavement. Additives are widely used for soil stabilisation since they are cheaper than other stabilisation 
methods. In recent years, there has been an increasing use of industrial waste for this purpose.

Delgado et al. (2006) carried out a study on the environmental impact and showed that the granite fines do not constitute a significant hazard to the quality of natural waters. Luodes et al. (2012) performed experimental work on granite, rapakivi granite, migmatite, syenite, diorite, gabbro, anorthosite gabbro, schist and soapstone, and showed that the waste rocks of Finnish natural stone quarries can generally be considered environmentally sound with potential uses in other industries.

There are a number of studies on the use of marble powder in the preparation of sub-bases in highway construction and the reuse of materials as aggregates in asphalt pavement (Akbulut and Gürer 2006; Üstünkol and Turabi 2009; Misra and Grupta 2009). Of the materials used in asphalt pavement, $95 \%$ are aggregates generated in nearby quarries and obtained from natural aggregate resources. The demand for aggregate means that more quarries has to be excavated; however, this destroys structure of the landscape and causes environmental damage. However, a significant amount of natural stone waste produced in the quarries has the potential of being reused as aggregates. Akbulut and Gürer (2006) showed that the marble from quarries can be reused as aggregates in the binder layers of light and medium trafficked asphalt. Üstünkol and Turabi (2009) investigated the use of industrial waste such as fly ash, phosphogypsum and glass powder as filler materials in asphalt concrete mixtures, and determined the acceptable values for filler materials.

The usability of waste granite and marble dust as an additive material in industrial brick was investigated, and found that the amount of granite and marble dust additive had positive effect on the physical, chemical and mechanical strength of the produced industrial brick. In addition, it is shown that granite and marble wastes can be added up to $50 \mathrm{wt} \%$ into the raw clay material in the production of bricks (Dhanapandian et al. 2009; Bilgin et al. 2012).

One of the studies is on the use of marble powder in concrete production. Ünal and Uygunoğlu (2003) investigated the effect of marble powder generated in quarries on the freezing-thawing durability of the concrete and found that 5-15\% fine marble powder added to concrete containing $350 \mathrm{~kg} / \mathrm{m}^{3}$ cement increased the freezing-thawing durability of the concrete. Almeida et al. (2007) showed in their study that natural stone slurry can be consumed by several industrial activities as a by-product and can specifically be used as a fine aggregate and/or microfiller in concrete mixtures, inducing benefits on its mechanical properties. Uysal (2010) demonstrated that marble powder increased the workability and durability of self-compacting concrete. Furthermore, Rashwan and Abou-Zeid (2012) examined the performance of concrete incorporating stone industry waste as aggregates and concluded that the stone by-products were suitable for concrete used in highly abrasive environments.

There are limited studies on soil stabilisation using natural stone wastes in the literature. Zorluer and Usta (2003) mixed soil samples with different percentages of marble powder to determine the swelling potential of the samples based on the dry weight of clay compacted at standard Proctor compaction energy and found that waste marble powder affected the swelling potential of clay. For his master's thesis, Başer (2009) prepared an artificial sample of expansive soil in the laboratory and added waste limestone powder and waste dolomitic marble powder to this sample. The analysis showed that increase in the stabiliser percentage resulted in a decrease in the swelling percentage and an increase in the rate of swelling. In addition, Başer (2009) concluded that the curing of samples positively affected the percentages and the rate of swelling. Agrawal and Grupta (2011) conducted a similar study and showed that the liquid limit $\left(w_{\mathrm{L}}\right)$, plasticity index $\left(I_{\mathrm{P}}\right)$ and swelling percentage decreased, whereas the plastic limit $\left(w_{\mathrm{P}}\right)$ increased with the increase in the percentage of the stabiliser. Ramadas et al. (2010) investigated the swelling and strength characteristics of expansive soil treated with stone dust and fly ash, and found that the plasticity characteristics of soil are low in case of soil treated with the stone dust compared to fly ash, and there is a decrease in optimum water content $\left(w_{\text {opt }}\right)$ and increase in maximum dry unit weight $\left(\gamma_{\mathrm{dmax}}\right)$ value with the increase in percentage of stone dust/fly ash. Ali and Koranne (2011) stated that there is a maximum improvement in strength properties for the combination of fly ash and stone dust as compared to fly ash/stone dust individually. Çimen (2010) showed in the project that pumice stone and marble powder wastes mixed with a small amount of lime can be used for filling, and moreover pumice and marble powder alone or pumice and marble powder mixed with lime can be used for soil improvement in high plasticity clayey soils. Çimen et al. (2011) investigated the effect of waste marble aggregates on the swelling pressure of compacted clay and found that the swelling pressure decreased with the increase in the percentage of marble aggregates and the decrease in the amount of additives resulted in more swelling. Taşpolat et al. (2006) studied the effect of marble powder used in the landfill liners on the freezing-thawing property of clay. They added different proportions of marble powder to the clay liner containing $10 \%$ bentonite and $90 \%$ kaolinite and performed tests on the freezingthawing property of the mixture. As a result of the study, it was concluded that the addition of 10 and $15 \%$ marble powder increased the durability of impermeable clay liners against environmental conditions. Misra and Grupta (2009) 
Table 1 Chemical composition of the materials used in the tests

\begin{tabular}{lrrrrrrrrrrrrrr}
\hline & $\mathrm{SiO}_{2}$ & $\mathrm{Al}_{2} \mathrm{O}_{3}$ & $\mathrm{Fe}_{2} \mathrm{O}_{3}$ & $\mathrm{MgO}$ & $\mathrm{CaO}$ & $\mathrm{Na}_{2} \mathrm{O}$ & $\mathrm{K}_{2} \mathrm{O}$ & $\mathrm{TiO}_{2}$ & $\mathrm{P}_{2} \mathrm{O}_{5}$ & $\mathrm{MnO}^{2} \mathrm{Cr}_{2} \mathrm{O}_{3}$ & $\mathrm{LOI}^{\mathrm{Total}}$ \\
\hline Bentonite & 55.47 & 16.7 & 4.57 & 2.08 & 2.68 & 3.00 & 1.89 & 0.57 & 0.32 & 0.08 & $<0.002$ & 12.30 & 99.94 \\
Kaolinite & 52.03 & 32.85 & 0.69 & 0.25 & 0.23 & 0.20 & 1.18 & 0.21 & 0.07 & $<0.01$ & 0.02 & 12.20 & 99.98 \\
Granite powder & 67.04 & 13.06 & 7.66 & 0.46 & 3.94 & 3.13 & 3.74 & 0.15 & 0.05 & 0.12 & 0.009 & 0.50 & 99.98 \\
Calcitic marble powder & 0.29 & 0.05 & $<0.04$ & 0.36 & 55.86 & 0.02 & 0.02 & $<0.01$ & $<0.01$ & $<0.01$ & $<0.002$ & 43.50 & 100.01 \\
Dolomitic marble powder & 0.09 & 0.03 & 0.24 & 21.21 & 30.56 & 0.01 & $<0.01$ & $<0.01$ & $<0.01$ & 0.01 & $<0.002$ & 47.50 & 99.63 \\
\hline
\end{tabular}

demonstrated that the addition of marble powder to sandy and clayey soil sub-bases in road construction significantly increased the California bearing ratio (CBR) values. Khan (2005) conducted tests on the waste marble powder as an additive in the stabilisation of cohesive soil to be used in the construction of dam cores and found that the permeability of the stabilised samples was reduced and the durability increased.

This study is important since to the best of our knowledge, it is the first study in the literature to compare the effectiveness of the waste calcitic marble, dolomitic marble and granite on the stabilisation of clays with different levels of plasticity. The results of this study will fill a gap in the literature and should be the basis for further studies on the determination of the appropriate natural stone waste to use for different soil types and in what amount.

\section{Materials and methods}

This study was conducted in two stages: first, a sufficient amount of waste sludge samples of calcitic marble, dolomitic marble and granite was obtained from processing plants located in the provinces of Afyon, Aydin and Kirşehir, Turkey. The waste samples were oven-dried at $60{ }^{\circ} \mathrm{C}$ to constant weight and the resulting powder was analysed in terms of chemical content, grain size distribution, unit weight, consistency limit and compaction. In addition, a petrographic test was performed on the rocks processed in the plants. In the second stage, the waste was added, at different percentages, to the artificially made clayey soil (containing bentonite and kaolinite) with different levels of plasticity. Changes in the parameters of particle distribution, unit weight, consistency limits and compaction parameters were examined, and the effect of natural stones and waste on the stabilisation of clayey soil with different levels of plasticity was assessed from the geotechnical engineering perspective.

In this study, the artificial clay samples were made from low plasticity kaolinite and high plasticity bentonite clays. The calcitic marble sludge was obtained from the waste of calcitic marble extracted from Afyon İscehisar quarries and processed in a plant in İscehisar; the dolomitic marble sludge was obtained from the waste of dolomitic marble extracted from Karacasu District of Aydin and processed in a plant in Sultanhisar District; and the granite sludge was obtained from the waste of granite extracted from Ortaköy District of Aksaray and processed in a plant in Kırşehir.

In this study, pycnometer (ASTM D 854-02), consistency limits (ASTM D 4318-00) and Standard Proctor compaction tests (ASTM D 698-07) were performed at the Geotechnical Laboratory of Department of Civil Engineering, Niğde University. The chemical analysis of the waste and clays used in these tests was conducted by Canada Acme Lab using the ICP-MS method. Table 1 shows the chemical content of the materials.

Kaolinite and bentonite clays were used to prepare three artificial clay samples: Clay A (95\% kaolinite $+5 \%$ bentonite), Clay B (90\% kaolin $+10 \%$ bentonite) and Clay C (80\% kaolinite $+20 \%$ bentonite). The waste was added to the artificially prepared clay

Table 2 Average index properties of artificial clays used in the tests

\begin{tabular}{llllllll}
\hline Materials & $\begin{array}{l}w_{\mathrm{L}} \\
(\%)\end{array}$ & $w_{\mathrm{P}}(\%)$ & $I_{\mathrm{P}}(\%)$ & $\begin{array}{l}\gamma_{\mathrm{s}} \\
\left(\mathrm{g} / \mathrm{cm}^{3}\right)\end{array}$ & $\begin{array}{l}w_{\mathrm{opt}} \\
(\%)\end{array}$ & $\begin{array}{l}\gamma_{\mathrm{dmax}} \\
\left(\mathrm{kN} / \mathrm{m}^{3}\right)\end{array}$ & $\mathrm{USCS}$ \\
\hline Clay A & 56 & 20 & 36 & 2.59 & 24.0 & 13.65 & $\mathrm{CH}$ \\
Clay B & 68 & 20 & 48 & 2.60 & 26.8 & 14.10 & $\mathrm{CH}$ \\
Clay C & 84 & 28 & 56 & 2.61 & 27.0 & 14.50 & $\mathrm{CH}$ \\
\hline
\end{tabular}

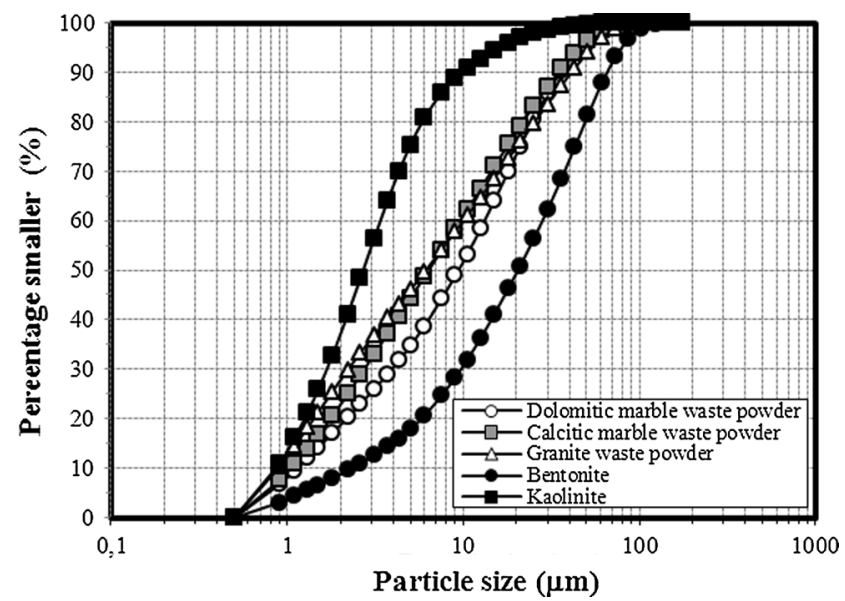

Fig. 2 The grain size distribution of materials in the tests 

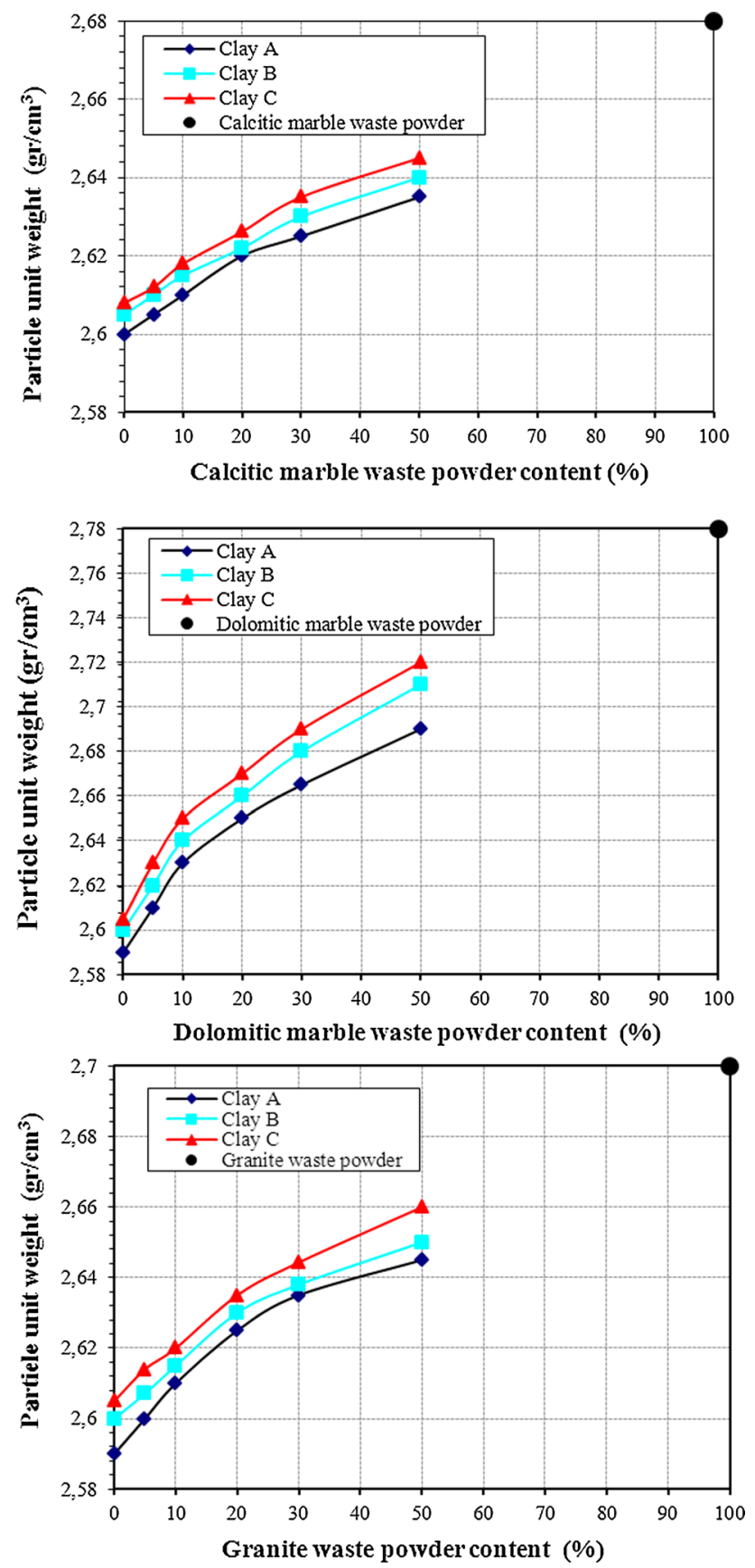

Fig. 3 Variation of unit weights of particles $\left(\gamma_{\mathrm{s}}\right)$ of the stone plant waste

samples at the percentages of $5,10,20,30$ and $50 \%$ by weight. Thus, the stabilised artificial clay specimens were obtained by adding the waste calcitic marble, dolomitic marble and granite sludge to the artificial clay samples at different percentages. The unit weight $\left(\gamma_{\mathrm{s}}\right)$, consistency limit $\left(w_{\mathrm{L}}, w_{\mathrm{P}}\right)$ and compaction tests were performed on non-stabilised and stabilised samples and the engineering parameters were obtained. The non-stabilised sample represents the artificial soil sample which is not stabilised
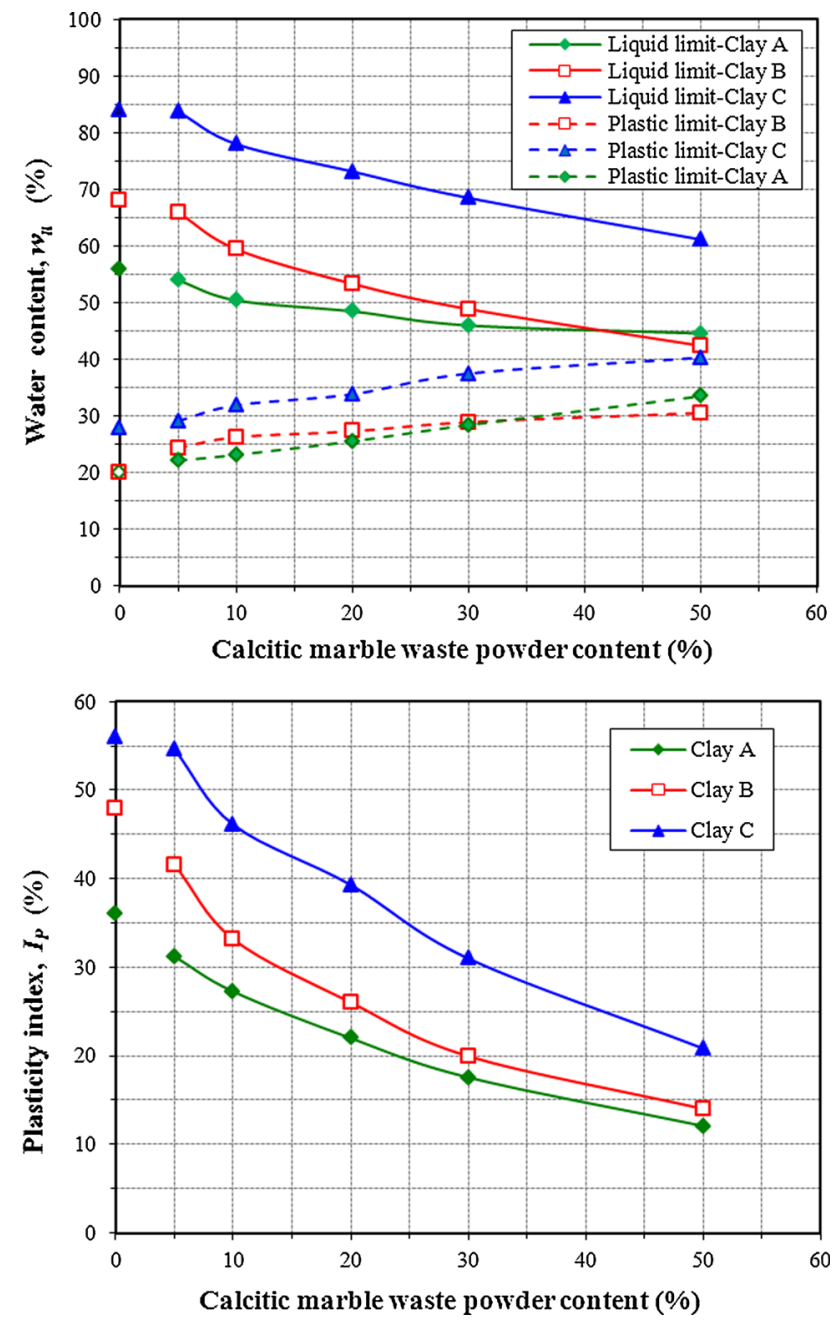

Fig. 4 Effect of calcitic marble waste powder on the liquid and plastic limits and plasticity index

with any waste, while the stabilised sample represents the artificial soil sample which is stabilised with any waste.The prepared artificial clays (Clay A, Clay B and Clay C) were classified as highly plasticity clay $(\mathrm{CH})$ according to the Unified Soil Classification System (USCS) (ASTM D 2487-00) and their index properties are given in Table 2.

\section{Results and discussion}

Index properties

The grain size distribution was analysed using laser diffraction on dry samples. Figure 2 shows the grain size distribution curve of the materials used in the tests.

Figure 3 shows the unit weight of the non-stabilised and stabilised samples with waste calcitic marble, dolomitic 

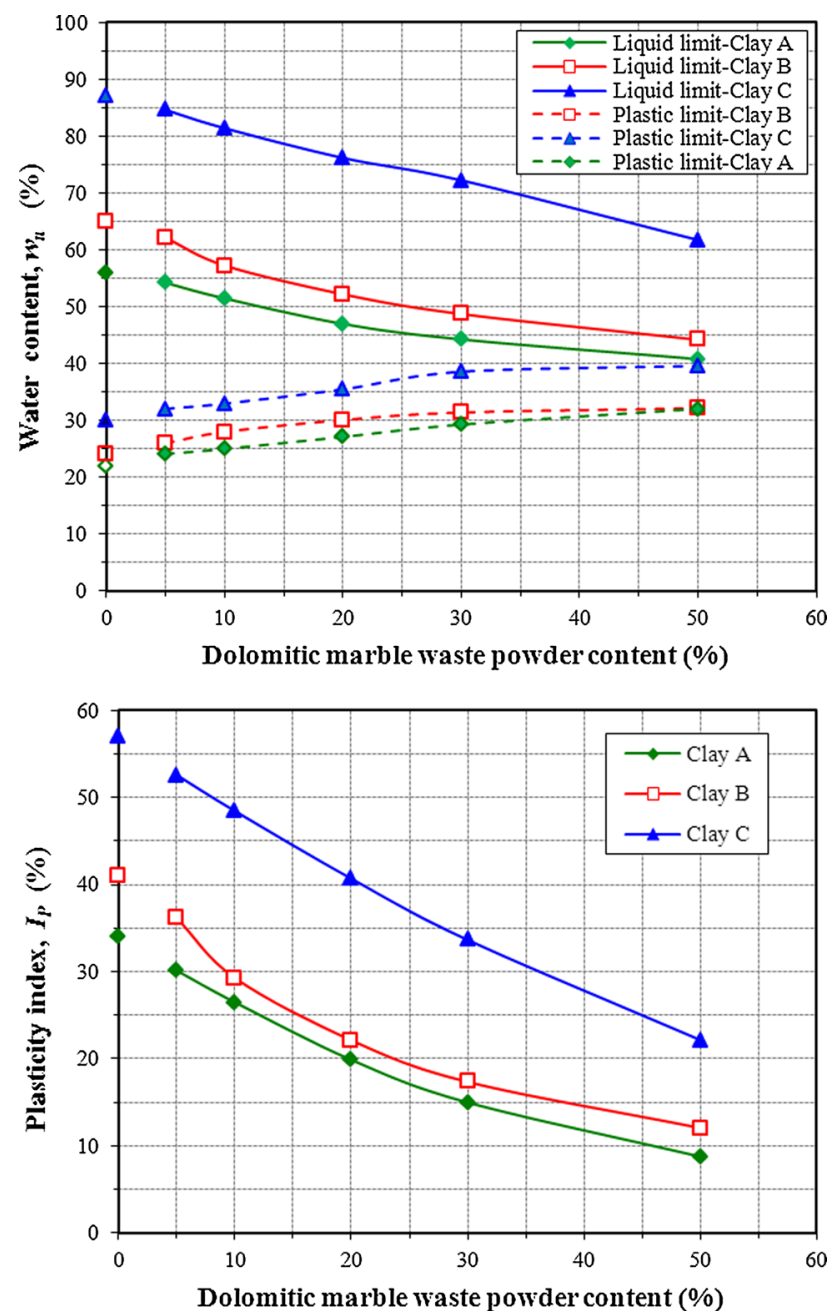

Fig. 5 Effect of dolomitic marble waste powder on the liquid and plastic limits and plasticity index

marble and granite. Since as expected the unit weight was higher than the unit weight of the soil samples, the increase in the percentages of waste also increased the unit weight of the stabilised soil samples. This result is compatible with that of study performed by Agrawal and Grupta (2011). In addition, the unit weight of calcitic marble powder $\left(\gamma_{\mathrm{s}}=2.68 \mathrm{~g} / \mathrm{cm}^{3}\right)$ and granite powder $\left(\gamma_{\mathrm{s}}=2.68 \mathrm{~g} / \mathrm{cm}^{3}\right)$ were similar. The higher unit weight of the dolomitic marble powder $\left(\gamma_{\mathrm{s}}=2.78 \mathrm{~g} / \mathrm{cm}^{3}\right)$ resulted in a higher unit weight for the soil sample stabilised with the dolomitic marble powder.

Consistency limit tests were performed on the nonstabilised and stabilised samples with waste calcitic marble, dolomitic marble and granite powder at various contents to determine their liquid and plastic limits. The liquid limit test was performed using the cone penetrometer method. The changes in the liquid limit, plastic limit and plasticity index of the stabilised samples of calcitic marble powder, dolomitic marble powder and
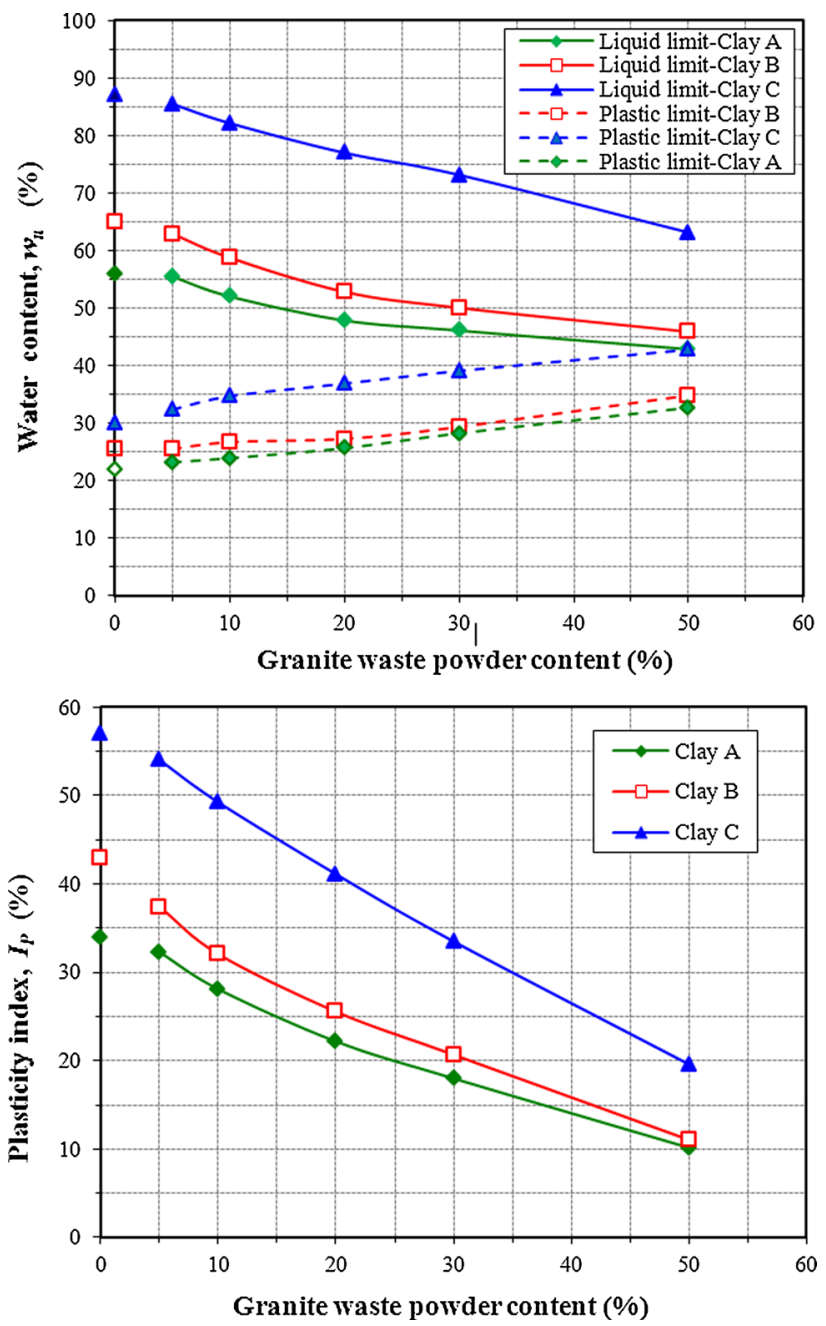

Fig. 6 Effect of granite waste powder on the liquid and plastic limits and plasticity index

granite powder are shown in Figs. 4, 5 and 6 respectively.

Each type of natural stone powder added to the samples decreased the liquid limit and increased the plastic limit. As the percentage of natural stone powder increased, the liquid limit of the stabilised samples decreased and the plastic limit increased, which in turn reduced the plasticity index. These results are consistent with the previous studies (Başer 2009; Ramadas et al. 2010; Çimen 2010; Agrawal and Grupta 2011) and in agreement with the assessment that the waste calcitic marble, dolomitic marble and granite can be utilised as additives in soil stabilisation.

The liquid limit decreased by $3 \%$ in the samples with $5 \%$ additives, whereas the decrease percentage was around 28 in the samples containing $50 \%$ additives. In parallel with the increase in the plasticity levels, the liquid limit decreased in the soil samples as follows: Clay A $\left(w_{\mathrm{L}}=56\right)$; Clay B $\left(w_{\mathrm{L}}=65\right)$ and Clay $\mathrm{C}\left(w_{\mathrm{L}}=87\right)$. The greatest decrease in the liquid limit in terms of the natural 

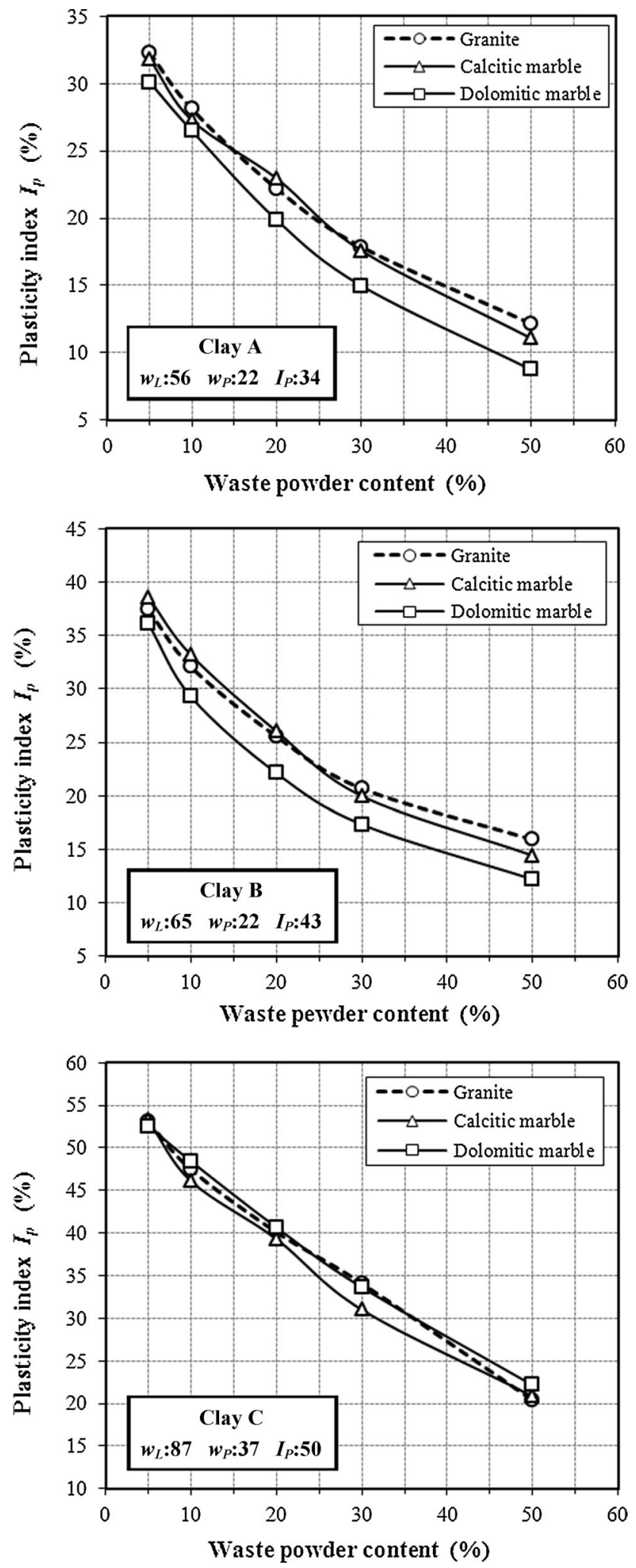

Fig. 7 Effect of types of stone plant waste powders on different plasticity clays

stone type was found in the sample containing dolomitic marble $(32 \%)$ followed by the samples containing calcitic marble $(28 \%)$ and granite powder $(27 \%)$. The plastic

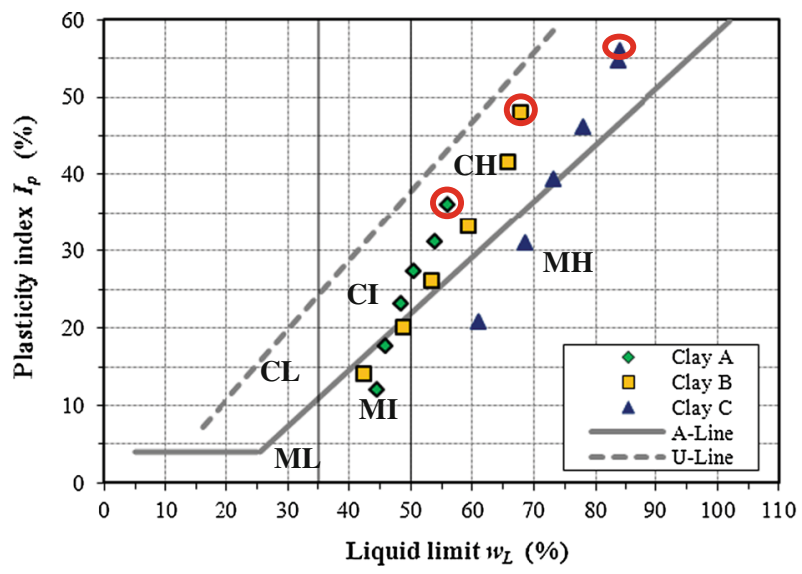

(a) Calcitic marble waste powder

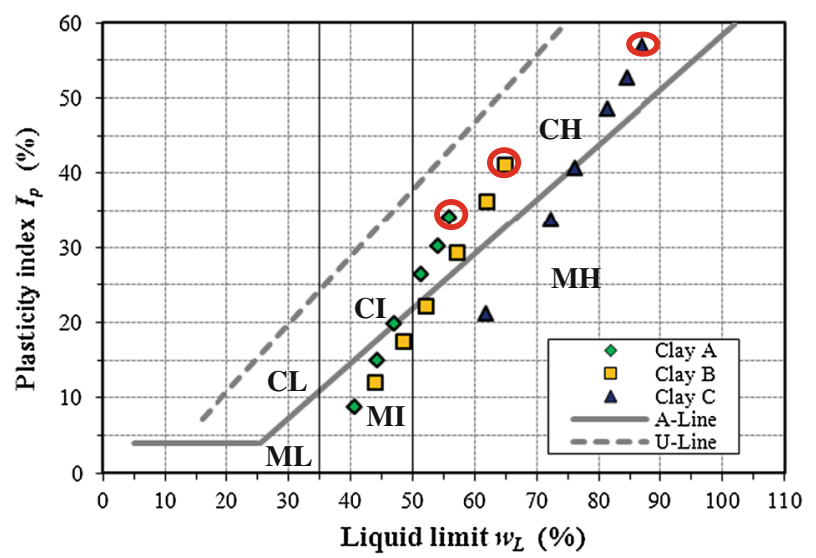

(b) Dolomitic marble waste powder

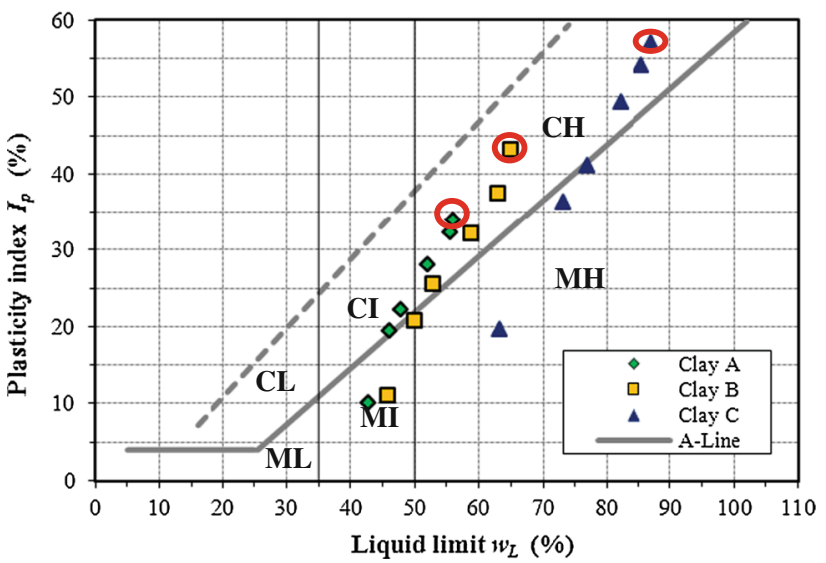

(c) Granite waste powder

Fig. 8 Changes of clays in the plasticity chart due to the effect of waste powders

limit decrease was found to be $5 \%$ in the samples with $5 \%$ additives and $41 \%$ in those with $50 \%$ additives. The highest decrease in the plastic limit was observed in Clay A $\left(w_{\mathrm{P}}=22\right)$ and Clay $\mathrm{B}\left(w_{\mathrm{P}}=22\right)$, and Clay $\mathrm{C}$ had a minor decrease in the liquid limit $\left(w_{\mathrm{P}}=30\right)$ (Figs. 4, 5, 6). The comparative analysis of the plastic limit between the 

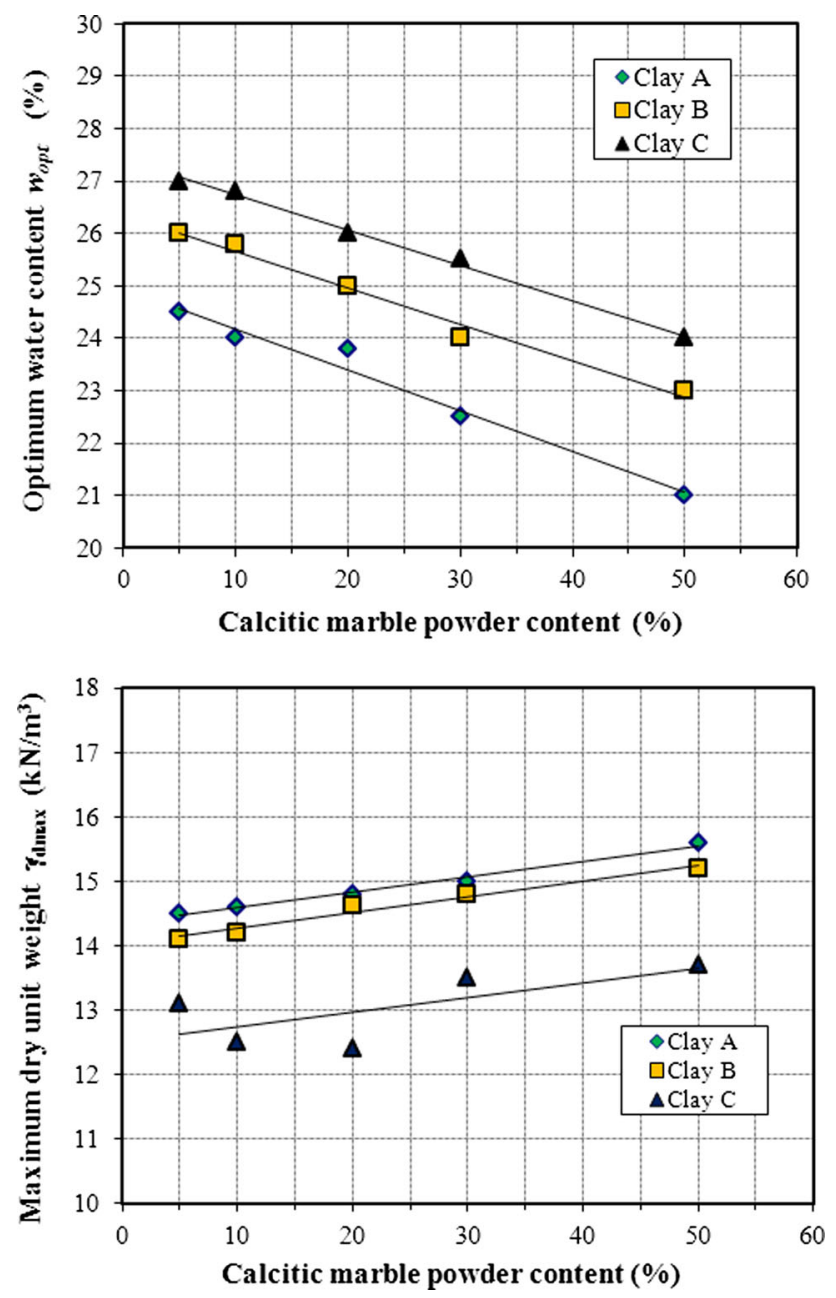

Fig. 9 Effect of calcitic marble waste powder on the compaction parameters

natural stone types showed that the highest decrease in the plastic limit was of the dolomitic marble (44\%) followed by calcitic marble (38\%) and granite powder $(39 \%)$. The rate of decrease in the liquid limit was found to be higher than that of the plastic limit.

Figure 7 shows the changes in the plasticity index of the clayey soil samples containing three different types of waste powder. The assessment of the charts shows that all three types of waste powder are effective in the stabilisation of clayey soils (in reducing the plasticity); however, the waste dolomitic powder is a better stabiliser (Fig. 7). There was a $9 \%$ decrease in the plasticity index of the samples with $5 \%$ additives, and $50 \%$ decrease in the samples with $66 \%$ additives. In parallel with the increase in the plasticity of soil samples, the highest decrease in the plasticity index was observed in Clay A $\left(I_{\mathrm{P}}=34\right)$ followed by Clay B $\left(I_{\mathrm{P}}=43\right)$ and Clay C $\left(I_{\mathrm{P}}=57\right)$. Furthermore, the highest decrease in terms of waste powder type was seen in dolomitic marble (32\%) (particularly in Clay A and Clay B), and all waste types used in the stabilisation of Clay C had similar values (Fig. 7).
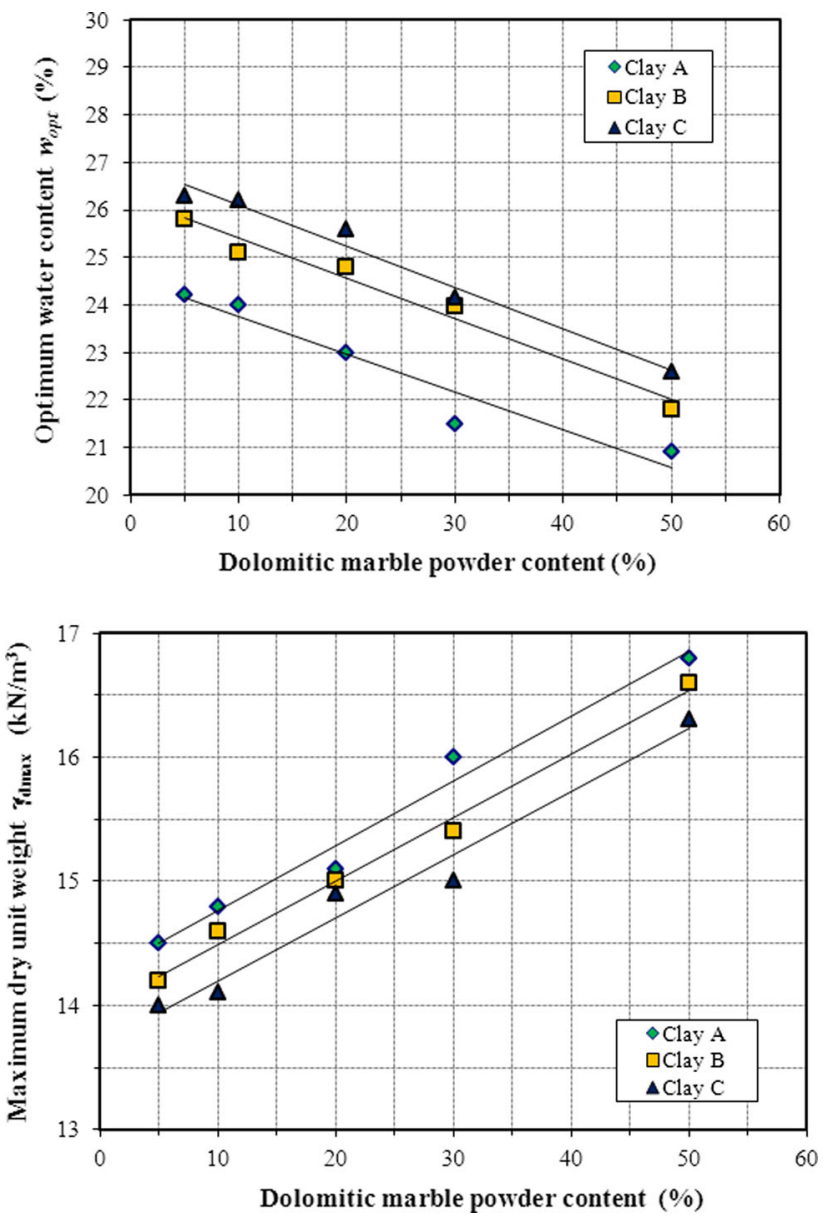

Fig. 10 Effect of dolomitic marble waste powder on the compaction parameters

Based on the plasticity chart, Fig. 8 shows the changes in the plasticity index of clayey soil samples with the effect of the waste calcitic marble, dolomitic marble and granite powder, respectively. The results of this study showed that these three different waste types reduced the plasticity of clayey soil, and as the stabiliser percentage increased, the soil samples shifted from high plasticity to low plasticity and also exhibited silty soil behaviour, which is more favourable in terms of workability (Fig. 8). This conclusion is consistent with the study carried out by Başer (2009).

In Fig. 8, the data of the non-stabilised samples are shown in circles. The waste powder that was most effective in terms of causing the shift from high to low plasticity and silty behaviour was found to be the waste dolomitic marble powder (at $20 \%$ and more).

\section{Compaction parameters}

The changes in the compaction parameters of three artificial clay samples were obtained by adding the waste calcitic marble, dolomitic marble and granite at different 

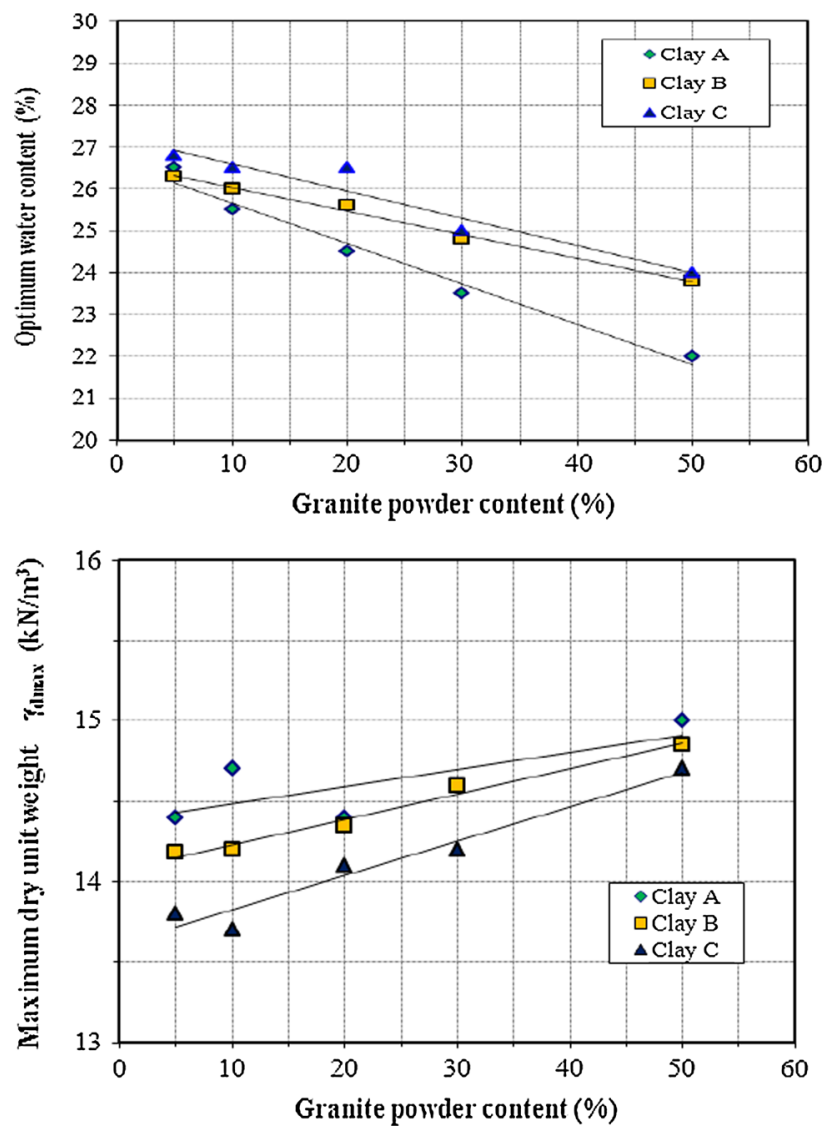

Fig. 11 Effect of granite waste powder on the compaction parameters

percentages were investigated. The changes in the optimum water content showed that as the percentage of waste increased, the optimum water content decreased and the maximum unit weight increased (Figs. 9, 10 and 11).

The effect of the waste types (calcitic marble, dolomitic marble and granite waste) on the compaction parameters of the soil samples with three different levels of plasticity (Clay A, Clay B and Clay C) was investigated individually. Figures 12, 13 and 14 show the changes in the compaction parameters of Clay A, Clay B and Clay C, respectively, depending on the waste type used.

It is found that the optimum water content decreases and maximum dry unit weight increases with the increasing waste ratio. This result complies with the previous studies (Ramadas et al. 2010; Çimen 2010). As the plasticity of the sample increased, the waste granite and calcitic marble were found to have a greater effect on the optimum water content than the waste dolomitic marble. In addition, the maximum dry unit weight of the samples containing waste dolomitic marble did not have a significant effect on the soil samples with different levels of plasticity. Compared with the other two waste types, the dolomitic marble
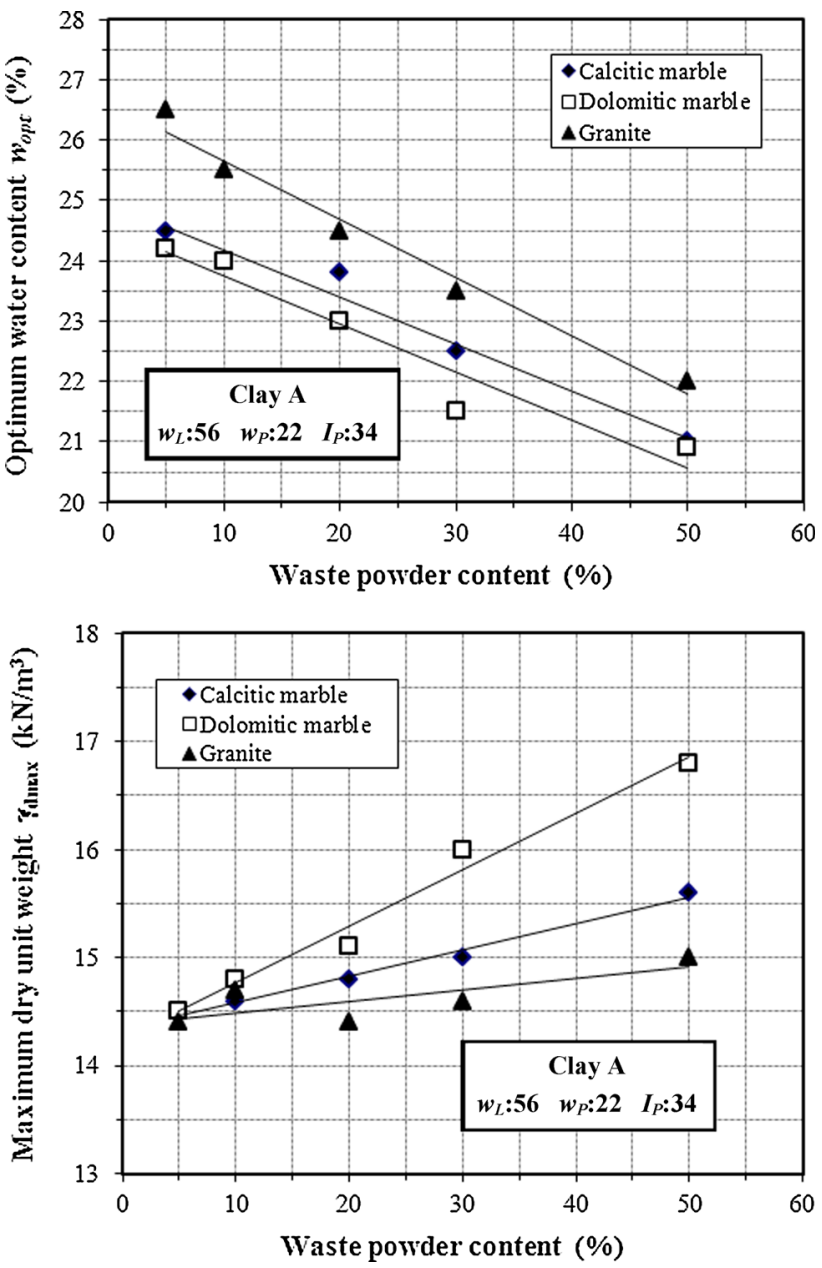

Fig. 12 Effect of the types of stone plant waste powder on the compaction parameters of Clay A

powder produced the lowest optimum water content and the highest maximum dry unit weight (Figs. 12, 13, 14).

\section{Conclusion}

In this study, the stabilised artificial clay samples were obtained by adding $5,10,20,30$ and $50 \%$ waste calcitic marble, dolomitic marble and granite powder to three artificial clays of different plasticities and then the effect of the different waste types on the consistency limits and compaction parameters of the samples was examined. The following conclusions were drawn from the results of the laboratory tests:

- The added waste powder increased the unit weight of the soil samples.

- All three types of natural stone waste added to the samples reduced the liquid limit and plasticity index of the samples and increased their plastic limits. The 

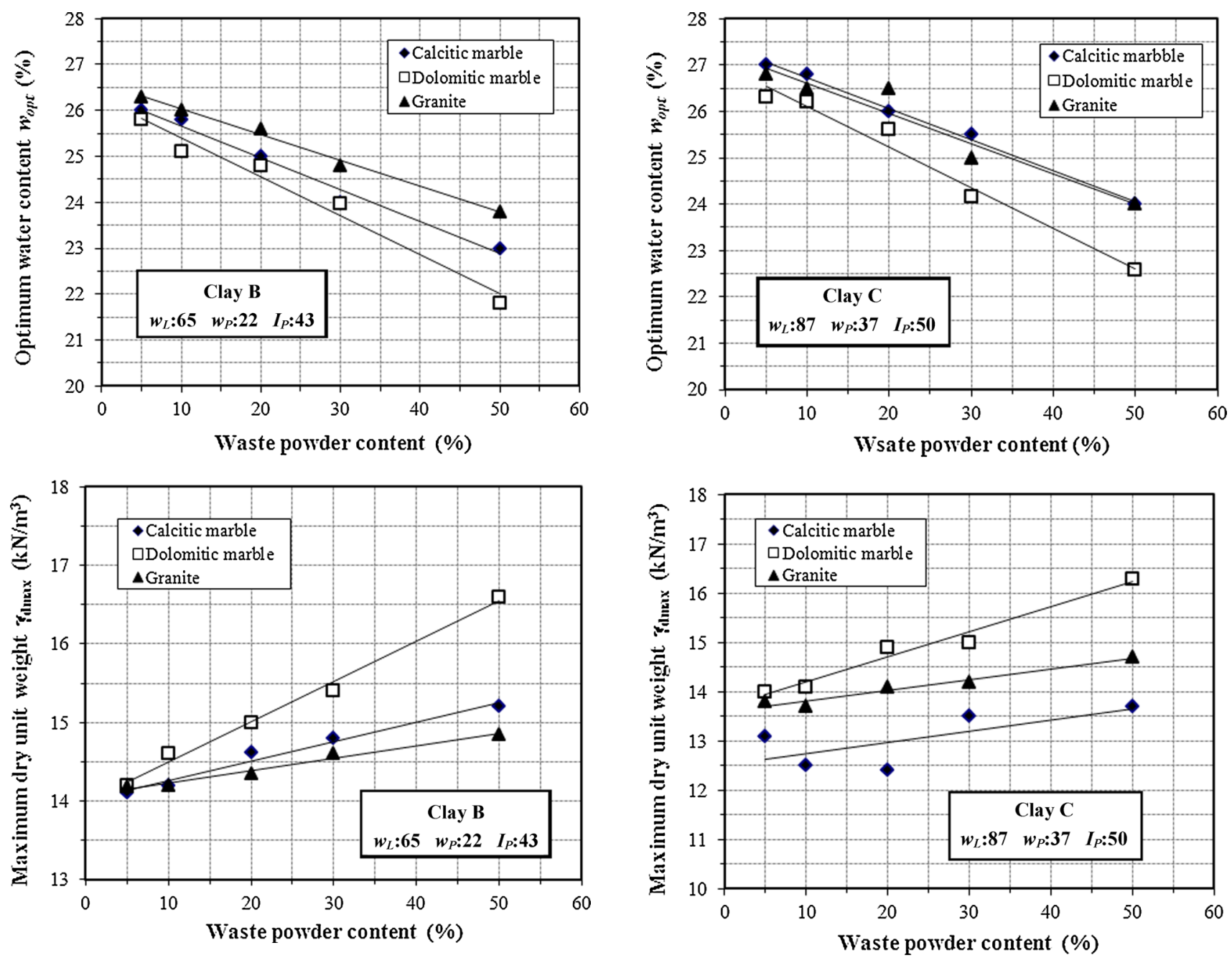

Fig. 13 Effect of the types of stone plant waste powder on the compaction parameters of Clay B

decrease in the liquid limit was found to be higher than the increase in the plastic limit.

- The soil sample that was most affected by the addition of waste natural stone powder was the high plasticity soil (Clay C). A comparative analysis of the different types of natural stone waste showed that granite and calcitic marble powder resulted in a similar change in the plasticity index, whereas after the addition of dolomitic marble powder, there was a greater change in the plasticity index.

- According to the plasticity chart, with the increase in the percentages of the added waste powder, the soil samples changed from having high plasticity to low plasticity and silty behaviour, which is favourable in terms of workability. The waste type that was most effective in promoting this shift was the waste dolomitic marble powder.

- The general assessment of the compaction parameters showed that all three types of natural stone waste

Fig. 14 Effect of the types of stone plant waste powder on the compaction parameters of Clay $\mathrm{C}$

powder decreased the optimum water content and increased the dry unit weight of the samples. A comparative analysis of the different types of natural stone waste revealed that the lowest optimum water content and the highest maximum dry unit weight resulted from the addition of the dolomitic marble powder.

- The optimum ratio of the wastes in the mixtures especially for Clay A and Clay B is around $30 \%$ and it needed a higher ratio for Clay $\mathrm{C}$.

- All the waste natural stone powder used in this study can be used as stabilisers; however, the waste dolomitic marble powder was found to be more effective as a stabiliser due to its chemical composition.

Acknowledgments This study is supported by Niğde University Scientific Research Projects Unit. This paper is partly benefited from the FEB 2010/33 project of Niğde University. The authors would like to thank Niğde University Scientific Research Projects Unit and the 
Niğde NIDAŞ Company for allowing them to use the laser diffraction device.

Open Access This article is distributed under the terms of the Creative Commons Attribution License which permits any use, distribution, and reproduction in any medium, provided the original author(s) and the source are credited.

\section{References}

Agrawal V, Gupta M (2011) Expansive soils stabilization using marble dust. Int J Earth Sci Eng 4:59-66

Akbulut H, Gürer C (2006) Use of waste marble as aggregate in asphalt pavement. IMO Teknik Dergi 17(4):3943-3960

Ali MS, Koranne SS (2011) Performance analysis of expansive soil treated with stone dust and fly ash. AJGE 16:973-982

Almeida N, Branco F, Santos JR (2007) Recycling of stone slurry in industrial activities: application to concrete mixtures. Build Environ 42(2):810-819

Al-Rawas AA, Taha R, Nelson JD, Beit Al-Shab T, Al-Siyabi H (2002) A Comparative evaluation of various additives in the stabilization of expansive soils. Geotech Test J 25(2):199-209

Altuncu D, Kasapseçkin MA (2011) Management and recycling of constructional solid waste, in Turkey. Int Conf Green Build Sustain Cities Proc Eng 21:1072-1077

ASTM D 2487-00 (2013) Standard practice for classification of soils for engineering purposes (Unified Soil Classification System). West Conshohocken, PA, USA

ASTM D 854-02 (2013) Standard test methods for specific gravity of soil solids by water pycnometer. West Conshohocken, PA, USA

ASTM D 4318-00 (2013) Standard test methods for liquid limit, plastic limit, and plasticity index of soils. West Conshohocken, PA, USA

ASTM D 698-07 (2013) Standard test methods for laboratory compaction characteristics of soil using standard effort. West Conshohocken, PA, USA

Başer O (2009) Stabilization of expensive soils using waste marble dust. MSc Thesis in Civil Engineering, Middle East Technical University, Ankara

Bilgin N, Yeprem HA, Arslan S, Bilgin A, Günay E, Marşoglu M (2012) Use of waste marble powder in brick industry. Constr Build Mater 29:449-457

Çimen Ö (2010) Investigation of utilization of pumice and marble powder wastes in soil improvement of high plasticity clay. Project No 109M344, TUBITAK (The Scientific and Technological Research Council of Turkey)

Çimen Ö, Keskin SN, Seven S, Erişkin E, Güllü D (2011) The effect of waste marble fracture on swelling pressure of compressed clay. In: 4th geotechnical symposium, 1-2 Aralık, Çukurova University, Adana, Turkey, pp 206-211

Delgado J, Va'zquez A, Juncosa R, Barrientos V (2006) Geochemical assessment of the contaminant potential of granite fines produced during sawing and related processes associated to the dimension stone industry. J Geochem Explor 88:24-27

Dhanapandian S, Gnanavel B, Ramkumar T (2009) Utilization of granite and marble sawing powder wastes as brick materials. Carpathian J Earth Environ Sci 4(2):147-160

Edil T (2011) Approach to sustainable geotechnical construction. In: 4th geotechnical symposium, 1-2 December, Çukurova University, Adana, Turkey, pp 56-64
Güllü H, Girisken S (2012) Performance of fine-grained soil treated with industrial wastewater sludge. Environ Earth Sci. doi:10. $1007 / \mathrm{s} 12665-012-2167-0$

Gürer C, Akbulut H, Kürklü G (2004) Recycling and re-evaluation of different building materials as a source of raw material in the construction industry. In: 5th Industrial raw materials symposium, 13-14 May, İzmir, Turkey, pp 28-36

Karaca Z (2009) Natural stone industry and environment. In: Symposium of evaluation of marble wastes and decreasing environmental effects, 16-17 October, Diyarbakır, Turkey, pp 325-338

Karaca Z, Pekin A, Deliormanlı AH (2012) Classification of dimension stone wastes. Environ Sci Pollut Res 19(6): 2354-2362

Khan SA (2005) Physical characteristics of fine soil stabilized with marble industry waste. In: 7th International Congress on Civil Engineering, Iran

Luodes H, Kauppila PM, Luodes N, Aatos S, Kallioinen J, Luukkanen S, Aalto J (2012) Characteristics and the environmental acceptability of the natural stone quarrying waste rocks. Bull Eng Geol Environ 71:257-261

Misra A, Grupta RC (2009) Environmental problems due marble powder waste and its utilization in road construction. In: Symposium of evaluation of marble wastes and decreasing environmental effects, 16-17 October, Diyarbakır, Turkey, pp 223-229

Mymrin VA (1997) Environment protection by industrial wastes utilization for engineering geology goals. In: International symposium on engineering geology and the environment, 23-27 June, Athens, Greece, 1-3:2027-2031

Ramadas TL, Kumar ND, Aparna G (2010) Swelling and strength characteristics of expansive soil treated with stone dust and fly Ash. In: Indian Geotechnical Conference-2010, GEOtrendz, 16-18 December, Bombay, pp 557-560

Rashwan MH, Abou-Zeid MN (2012) Performance of concrete incorporating stone industry waste as aggregates. Transp Res Rec 2290:122-129

Sarısoy S (2010) Domestic production of granite. In: 2nd International Congress on the Marble and Natural Stones İzmir, 2-4 February, Turkey, pp 155-164

Taşpolat LT, Zorluer İ, Koyuncu H (2006) The effect of marble waste powder on the freeze-thaw in impermeable clay layers. Electron J Constr Technol 2:11-16

Ünal O, Uygunoğlu T (2003) Investigation of mechanical properties of concretes with waste marble powder under the effect of freeze-thaw. In: Turkish 4th marble symposium, 18-19 December, Afyon, pp 147-157

Üstünkol FN, Turabi A (2009) Evaluation of industrial waste in the superstructure of the road. BAÜ FBE J 11(1):15-27

Uysal M (2010) The effect of marble powder on the workability and strength properties of self-compacting concrete. In: 2nd International Congress on the Marble and Natural Stones İzmir, 2-4 February, Turkey, pp 326-334

Wang L (2002) Cementitious stabilization of soils in the presence of sulfate. Ph.D. Thesis, Louisiana State University

Zega CJ, Villagran-Zaccardi YA, Di Maio AA (2010) Effect of natural coarse aggregate type on the physical and mechanical properties of recycled coarse aggregates. Mater Struct 43:195-202

Zorluer İ, Usta M (2003) Soil improvement with waste marble powder. In: Turkish 4th marble symposium, 18-19 December, Afyon, pp 305-311 